\title{
Influence of PGPR and Zinc Enriched FYM on Growth and Yield of Rice at Different Levels of Phosphors in an Inceptisol of Varanasi, India
}

\author{
Kanhaiya Lal Regar* and Janardan Yadav \\ Department of Soil Science and Agricultural Chemistry, Institute of Agricultural Sciences, \\ BHU, Varanasi, India \\ *Corresponding author
}

\section{A B S T R A C T}

Field experiments were carried out during Kharif seasons of 2013-14 and 2014-15 at the Agricultural Research Farm, Banaras Hindu University, Varanasi (U.P.) to study the effect of PGPR and Zinc enriched FYM on yield and growth attributes of rice at different levels of phosphors in an Inceptisol of Varanasi. The treatments consisted five levels of enriched

\begin{tabular}{|l|}
\hline Key w or d s \\
PGPR and Zinc \\
enriched FYM, \\
Phosphorus, Rice \\
Yield and growth \\
attributes. \\
\hline Article Info \\
\hline Accepted: \\
12 March 2017 \\
Available Online: \\
10 April 2017 \\
\hline \hline
\end{tabular}
FYM ( $\mathrm{M}_{0}=$ No FYM, $\mathrm{M}_{1}=$ only FYM, $\mathrm{M}_{2}=$ PGPR enriched FYM, $\mathrm{M}_{3}=$ PGPR and $\mathrm{Zn} @$ $2.5 \mathrm{~kg} \mathrm{ha}^{-1}$ enriched FYM and $\mathrm{M}_{4}=$ PGPR and Zn @ $5.0 \mathrm{~kg} \mathrm{ha}^{-1}$ enriched FYM) and four levels of phosphors $\left(0,20,40\right.$ and $\left.60 \mathrm{~kg} \mathrm{P}_{2} \mathrm{O}_{5} \mathrm{ha}^{-1}\right)$. The experiment was replicated thrice in a Randomized block design in Factorial experiment. The results showed that, the application of PGPR and Zinc enriched FYM was significantly increased the yield and growth attributes of rice. All the growth and yield attributes showed that treatment $\mathrm{M}_{4}$ was found significantly highest over all the treatments but it was at par with treatment $\mathrm{M}_{3}$ except plant height. As regards the 4 levels of phosphors $\left(0,20,40\right.$ and $60 \mathrm{~kg} \mathrm{P}_{2} \mathrm{O}_{5}$ ha $\left.^{-1}\right)$, an application of $60 \mathrm{~kg} \mathrm{P}_{2} \mathrm{O}_{5}$ gave the significant highest result over the control and all other treatments for yield and growth attributes of rice except chlorophyll content. Interactive effects of enriched FYM and phosphorus levels were found significant on plant height, grain yield, straw yield and biological yield. Application of PGPR and Zn @ $5.0 \mathrm{~kg}$ ha $^{-1}$ enriched FYM along with $60 \mathrm{~kg} \mathrm{P}_{2} \mathrm{O}_{5} \mathrm{ha}^{-1}$ resulted in markedly higher plant height $(109.07 \mathrm{~cm})$, grain yield $\left(59.62 \mathrm{q} \mathrm{ha}^{-1}\right)$, straw yield $\left(79.94 \mathrm{q} \mathrm{ha}^{-1}\right)$ and biological yield (139.56 $\mathrm{q} \mathrm{ha}^{-1}$ ) but showed at par result with PGPR and Zn @ $2.5 \mathrm{~kg} \mathrm{ha}^{-1}$ enriched FYM applied in conjunction with $40 \mathrm{~kg} \mathrm{P}_{2} \mathrm{O}_{5} \mathrm{ha}^{-1}$. The aim of this experiment was to minimize excess use of fertilizers for optimum yield and quality of rice without harming soil and environment health by the application of PGPR and Zinc enriched FYM.

\section{Introduction}

Rice (Oryza sativa L.) crop is a principal source of staple food for more than half of the world population and hence becomes a main source of Zinc to human (Fitzgerald et al., 2009). This crop is an important energy source of more than half of the world and $65 \%$ of the Indian population (Liu et al., 2008). It is an important crop in India which occupied 43.40 million hectare area with the production of 157.20 million tonnes and have $3.62 \mathrm{t} \mathrm{ha}^{-1}$ productivity which is less than world's average productivity (4.52 $\left.\mathrm{t} \mathrm{ha}^{-1}\right)$ (FAO, 2014). To meet the future food requirements of ever increasing population and maintain self sufficiency, the estimated rice production in India is targeted at 350 
million tonnes by $2020 \mathrm{AD}$ (Veeraputhiran and Balasubramanian, 2013).

Phosphorous is a second an essential plant nutrient after nitrogen, whose deficiency restricts growth and yield of crop severely. The low level of phosphorous is due to high reactivity of soluble phosphate with other elements in soil. The phosphate solubilizing micro-organisms increase the potential availability of soluble phosphates and they also enhance plant growth by increasing the efficiency of biological nitrogen fixation or enhancing the availability of trace elements to plants such as iron, zinc etc., and by production of plant growth promoting regulators (Ponmurugan and Gopi, 2006). Many plant growth promoting rhizobacteria are able to solubilise fixed phosphates in the soil, usually by releasing chelating organic acids and increase the acquisition to plants (Vessey et al., 2004).

Rice crop requires high amount of Zn (Brady and Weil, 2007; Havlin et al., 2007), under deficient condition of $\mathrm{Zn}$ in soil, therefore $\mathrm{Zn}$ deficiency becomes in the rice plants, then plant growth is restricted and quality of rice grain deteriorates and human health is also adversely affected (Pathak et al., 2008; Singh, 2010). To ameliorate $\mathrm{Zn}$ deficiency in the Zinc deficient soils, the Zn fertilizers are being used but the $\mathrm{Zn}$ availability is less to the plants due to very high $\mathrm{Zn}$ fixation in soil. Organic manures provide major as well as minor nutrients and improve soil health by improving physical condition of soil. The combined use of inorganic fertilizers with organic manures namely, farmyard manure (FYM), green manure, poultry manure, pig manure increased the rice yield, Nitrogen, Phosphorus and Potassium uptake, use efficiency of nutrients and available nutrient status of soil (Laxminarayana, 2006; Laxminarayana and Patiram, 2006).
The recovery of micronutrients is very poor in crop that necessitates the adoption of improved techniques like use of micronutrients synthetic chelates. Since it is a costly technology, therefore enrichment of soil with organic manures and micronutrients, which acts as natural chelates in the soil, seems to be economically viable. Zinc application in the enriched form with organic manure, enhances the fertilizer use efficiency and increases the rice yield. The enrichment of micronutrients with organic manures not only enhances the rate of decomposition but also improves the nutrient status and health of soil (Singh, 1987).

In the last few years, the number of PGPR strain has seen a great importance, mainly due to role of the rhizosphere as an ecosystem that gained importance in the functioning of the biosphere. Various species of rhizobacteria like Pseudomonas, Azospirillum, Azotobacter, Klebsiella, Enterobacter, Alcaligenes, Arthrobacter, Burkholderia, Bacillus and Serratia have been reported to enhance the plant growth by providing nutrients and Phytohormones (Joseph et al., 2007).

The use of Plant Growth Promoting Rhizobacteria offers an attractive way to replace chemical fertilizer (as biofertilizer), pesticides (as biocontrol), and supplements; most of the PGPR isolates result in a significant increase in plant height, root length, and dry matter production of shoot and root of plants. They also help in the suppression of disease in plants. PGPR is as a component factor in the integrated management systems in which reduced rates of agrochemicals and cultural control practices are used as biocontrol agents (Kloepper et al., 2004). Considering all facts as given above, the aim of this experiment was reducing the excess use of chemical fertilizer and to increase the use efficiency of nutrients. Therefore, Yield and quality of rice 
could be increase by using zinc and PGPR enriched FYM.

\section{Materials and Methods}

A field experiment was conducted during the Kharif season of 2013-14 and 2014-15 at the Agricultural Research Farm, Institute of Agricultural Sciences, BHU, Varanasi $\left(25^{\circ}\right.$ $18^{\prime} \mathrm{N}, 88^{\circ} 03^{\prime} \mathrm{E}$ and $128.93 \mathrm{~m}$ above mean sea-level). District Varanasi is in semi-arid to sub humid climate zone, mean maximum temperature ranged from 21.1 to $36.7^{\circ} \mathrm{C}$ and while minimum temperature from 6.2 to 28.7 ${ }^{\circ} \mathrm{C}$. The mean annual rainfall is about 1,100 $\mathrm{mm}$. The soil belongs to Inceptisol, had sandy loam texture, particle density $2.68 \mathrm{Mg} \mathrm{m}^{-3}$, bulk density $1.41 \mathrm{Mg} / \mathrm{m}^{3}, \mathrm{pH}$ (1:2.5, soil: water) 8.04 ; electrical conductivity $0.21 \mathrm{dSm}^{-1}$ organic carbon $0.37 \%$ and available nitrogen $195.40 \mathrm{~kg} \mathrm{ha}^{-1}$, available phosphorus $18.20 \mathrm{~kg}$ $\mathrm{ha}^{-1}$ and available potassium $203.50 \mathrm{~kg} \mathrm{ha}^{-1}$. A total of 20 treatment combinations comprising of five levels of PGPR and Zinc enriched FYM $\left(\mathrm{M}_{0}=\right.$ No FYM, $\mathrm{M}_{1}=$ only FYM, $\mathrm{M}_{2}=$ PGPR enriched FYM, $M_{3}=$ PGPR and Zn @ $2.5 \mathrm{~kg} \mathrm{ha}^{-1}$ enriched FYM and $\mathrm{M}_{4}=$ PGPR and Zn @ $5.0 \mathrm{~kg} \mathrm{ha}^{-1}$ enriched FYM) and four levels of phosphors $\left(0,20,40\right.$ and $60 \mathrm{~kg} \mathrm{P}_{2} \mathrm{O}_{5}$ $\mathrm{ha}^{-1}$ ) with 3 replications under Randomized block design in Factorial experiment. The enriched FYM was applied @ 5 tonnes tonnes $\mathrm{ha}^{-1}$ in experimental field as per treatments. Full dose of potassium and half dose of nitrogen were applied at the time of transplanting of rice seedling. Twenty five days old seedlings of rice 'HUR 105' were transplanted at a spacing of $20 \mathrm{~cm} \times 20 \mathrm{~cm}$. Remaining half dose of nitrogen at 25 DAT. $\mathrm{N}, \mathrm{P}_{2} \mathrm{O}_{5}$ and $\mathrm{K}_{2} \mathrm{O}$ were applied through urea, di-ammonium phosphate (DAP) and muriate of potash (MOP) respectively. Rice was sown in the first week of August and harvested during last week of November during 201314 and 2014-15. All improved packages of practices were followed to raise the crop.
Yield components and the grain and straw yields were recorded at harvest and the data were statistically analysed.

\section{Preparation of enriched FYM}

The known quantity of FYM was filled in four pits. The solution of $\mathrm{ZnSO}_{4} .7 \mathrm{H}_{2} \mathrm{O}$ was prepared on the basis of 2.5 and $5.0 \mathrm{~kg} \mathrm{Zn} \mathrm{ha}$ ${ }^{1}$ and thoroughly mixed in respective pits of known quantity of FYM as required of one hectare of soil. After 21 days, a composite microbial culture consisting of PGPR consortium (Azospirillum brasiliense, Pseudomonas fluorescens, Pseudomonas aeruginosa, Bacillus subtilis, Paenibacillus polymyxa, Trichoderma harzianum) was added and thoroughly mixed to ensure complete contact with the decomposing materials (FYM). PGPR consortium was added after 21 days of initial composting to protect the microbes from direct exposure to excess heat generated from the materials. The moisture percentage of organic manures after mixing with $\mathrm{ZnSO}_{4} .7 \mathrm{H}_{2} \mathrm{O}$ and PGPR was maintained around $60 \%$ throughout enrichment process. The cattle dung slurry @ $1 \%$ was applied as starter inoculums of microorganism to boost up the microbiological activities for enhancement of natural process of composting to fix the externally added $\mathrm{Zn}$ through zinc sulphate. The pits were covered by polythene sheet and allowed to decompose. The mixture was turned over weekly and also maintained moisture.

\section{Results and Discussion}

\section{Effect of PGPR and zinc enriched FYM}

Growth and yield attributes as well as grain and straw yields of rice were significantly influenced by different type of enriched FYM (Table 1,2 and 3) Chlorophyll content, plant height, tillers hill $^{-1}$, grains panicle $^{-1}$, test 
weight, yields and harvest index of rice were significantly highest in the treatment of FYM enriched with PGPR and zinc @ $5 \mathrm{~kg} \mathrm{ha}^{-1}$ $\left(\mathrm{M}_{4}\right)$ over the other treatments and remained at par with the treatment of FYM enriched with PGPR and zinc @ $2.5 \mathrm{~kg} \mathrm{ha}^{-1}\left(\mathrm{M}_{3}\right)$ except plant height.

The beneficial effect of enriched FYM with PGPR and $\mathrm{Zn}$ was clearly noticed over without enriched FYM and control in rice. The data presented in table 1 revealed that chlorophyll content was found highest in the treatment $\mathrm{M}_{4}$ but remained at par to treatment $\mathrm{M}_{3}$ and rest of the treatments were significant to each other and over the control. Data showed in table 2 that plant height significantly increased by application of different types of enriched FYM. Highest plant height $(106.44 \mathrm{~cm})$ was in the treatment $\mathrm{M}_{4}$ and lowest plant height $(91.44 \mathrm{~cm})$ was found in $\mathbf{M}_{0}$ which is control. Treatment $\mathbf{M}_{4}$ and $\mathrm{M}_{3}$ gave at par result in case of increasing number of tillers hill $^{-1}$. Treatment $\mathrm{M}_{3}$ was significantly increased tillers hill $^{-1}$ over the treatment $\mathrm{M}_{2}, \mathrm{M}_{1}$ and control. Treatment $\mathrm{M}_{3}$, $\mathrm{M}_{2}$ and $\mathrm{M}_{1}$ were increased by 51.8, 36.6 and $17.4 \%$, respectively over the control. Grains panicle $^{-1}$ was found highest (133.77) in the treatment $\mathrm{M}_{4}$ but it was at par with $\mathrm{M}_{3}$ and order of increasing no. of grains was $\mathrm{M}_{0}<\mathrm{M}_{1}$ $<\mathrm{M}_{2}<\mathrm{M}_{3}<\mathrm{M}_{4}$. Test weight value was found lowest $(22.21 \mathrm{~g})$ in control while significantly highest value of test weight (23.77 g) was recorded in treatment $\mathrm{M}_{4}$ which was at par with $\mathrm{M}_{3}$.

The result of the investigation showed in table 3 that grain and straw yield varied between 40.57 to 56.92 and 56.21 to $76.83 \mathrm{q} \mathrm{ha}^{-1}$, respectively. Grain yield significantly increased over control due to application of PGPR and Zn enriched FYM. Highest grain yield $\left(56.92 \mathrm{q} \mathrm{ha}^{-1}\right)$ was obtained in the treatment $\mathrm{M}_{4}$ which is increased $40.3 \%$ over control but it was at par with treatment $\mathrm{M}_{3}$ while remaining treatment showed significantly differ to each other. Similar result was also found in the straw yield. Highest straw yield was observed in $\mathrm{M}_{4}$ which was at par with $\mathrm{M}_{3}$ and $\mathrm{M}_{3}$ was increased $34.4 \%$ over control.

Data related to biological yield of rice was ranged from 96.78 to $133.75 \mathrm{q} \mathrm{ha}^{-1}$. Biological yield increased highest in treatment $\mathrm{M}_{4}$ and lowest value was found in the treatment $\mathrm{M}_{0}$ which was control. Harvest Index was also influenced by PGPR and $\mathrm{Zn}$ enriched FYM. All the treatments were not significant to each other but it was increased with addition of different types of FYM (Table 3). It might be due to enrichment of FYM with PGPR and $\mathrm{Zn}$ which provides nutrients in available form like $\mathrm{N}, \mathrm{P}$ and other essential nutrients, growth stimulating hormones along with chelated $\mathrm{Zn}$ which is available to plant during growth period and FYM also improves the physico-chemical and biological properties of soil. The result reveals that application of FYM increased yield parameters as compare to control (no FYM) might be due to its successive decomposition that enabled the wheat crop to ensure an almost continuous supply of nutrients efficiently throughout the growth period of crop (Patil et al., 1998) and along with it is also improved the physical, chemical and biological properties of soil. The results are in line with the findings of Kumar and Singh, (2010). The results are in accordance with those reported by Kumar (1999), Jena (2006) Sudhakar et al., (2006) and Meena et al., (2006).

\section{Effect of levels of phosphorus}

Tables 1, 2 and 3 shows that yield and growth attributes viz. Chlorophyll content, Plant height, and no. of tillers hill ${ }^{-1}$, markedly influenced by phosphorus levels which were highest at $60 \mathrm{~kg} \mathrm{P}_{2} \mathrm{O}_{5} \mathrm{ha}^{-1}$ and proved 
significantly superior to other lower dose of phosphorus.

Result indicates that application of $60 \mathrm{~kg} \mathrm{P}_{2} \mathrm{O}_{5}$ ha $^{-1}$ significantly increased the Chlorophyll (SPAD value) by 37.32 over control (33.39). Plant height observed significantly greater in the treatment $P_{3}(103.85 \mathrm{~cm})$ and the effect of the treatments on other yield attributes as number of tillers hill ${ }^{-1}$, grains panicle ${ }^{-1}$ and test weight $(\mathrm{g})$ were also depicted similar trends where obtained highest value 14.42, 132.02 and 23.70 , respectively were recorded under $\mathrm{P}_{3}$ treatment.

Grain yield was observed highest (54.24 q ha ${ }^{1}$ ) in the treatment $\mathrm{P}_{3}$ which was increased $21.6 \%$ to control. Straw yield also increased gradually with increasing dose of $\mathrm{P}_{2} \mathrm{O}_{5}$ and lowest straw yield $\left(61.42 \mathrm{q} \mathrm{ha}^{-1}\right)$ was obtained in the control which increased up to $73.61 \mathrm{q}$ $\mathrm{ha}^{-1}$ in treatment $\mathrm{P}_{3}\left(60 \mathrm{~kg} \mathrm{P}_{2} \mathrm{O}_{5}\right)$. Similarly biological yield was increased with application of different dose of $\mathrm{P}_{2} \mathrm{O}_{5}$. It was significantly highest due to application of 60 $\mathrm{kg} \mathrm{P}_{2} \mathrm{O}_{5}$ which increased $20.6 \%$ over the control. Statistically, harvest index (\%) was not influenced by addition of different levels of Phosphorus and showed non-significant result. It might be due to optimum dose of fertilizers $\left(120 \mathrm{~kg} \mathrm{~N} \mathrm{ha}^{-1}, 60 \mathrm{~kg} \mathrm{P}_{2} \mathrm{O}_{5} \mathrm{ha}^{-1}\right.$ and $60 \mathrm{~kg} \mathrm{~K}_{2} \mathrm{O} \mathrm{ha}^{-1}$ ) because $60 \mathrm{~kg} \mathrm{P}_{2} \mathrm{O}_{5}$ was applied as a treatment $\mathrm{P}_{3}$ and $\mathrm{N}$ and $\mathrm{K}_{2} \mathrm{O}$ were added as recommended dose in the whole experimental field.

The improvement in growth and yield attributes was might be due to the supply of available form of NPK fertilizers. Except that plant processes viz. cell division and root elongation in merismatic tissues and component of ADP and ATP in plant cell followed by a large canopy development by the increased levels of fertilizer seems to have a greater absorption and utilization of radiant energy resulting high growth and yield attributing characters of crop plants (Sharma et al., 2012). Meena et al., (2015) also reported that addition of highest levels of Phosphorus $\left(60 \mathrm{~kg} \mathrm{P}_{2} \mathrm{O}_{5} \mathrm{ha}^{-1}\right)$ along with bio organics increases the highest yield and growth attributes of rice.

\section{Interaction effect of Enriched FYM and Phosphorus levels}

Interaction between different levels of enriched FYM and phosphorus on plant height, grain yield, straw yield and biological yield of rice were found significant (Table 4). Combined application of PGPR and Zinc @ 5 $\mathrm{kg} \mathrm{ha}^{-1}$ enriched FYM $+60 \mathrm{~kg} \mathrm{ha}^{-1} \mathrm{P}_{2} \mathrm{O}_{5}$ was recorded highest grain yield $\left(59.62 \mathrm{q} \mathrm{ha}^{-1}\right)$ but it was at par with PGPR and zinc @ $2.5 \mathrm{~kg} \mathrm{ha}^{-}$ ${ }^{1}$ enriched $\mathrm{FYM}+40 \mathrm{~kg} \mathrm{ha}^{-1} \mathrm{P}_{2} \mathrm{O}_{5}$ which had minimum input over rest of the other closest treatment combinations $\left(\mathrm{M}_{3} \mathrm{P}_{3}\right.$ and $\left.\mathrm{M}_{4} \mathrm{P}_{2}\right)$.

Further, the data indicates that straw yield (79.94 $\left.\mathrm{q} \mathrm{ha}^{-1}\right)$ and biological yield (139.56 q $\mathrm{ha}^{-1}$ ) were highest in the treatment combination of PGPR and Zinc@5 kg ha ${ }^{-1}$ enriched $\mathrm{FYM}+60 \mathrm{~kg} \mathrm{P}_{2} \mathrm{O}_{5} \mathrm{ha}^{-1}$. It was also at par with $\mathrm{M}_{3} \mathrm{P}_{2}$ and other $\left(\mathrm{M}_{3} \mathrm{P}_{3}\right.$ and $\left.\mathrm{M}_{4} \mathrm{P}_{2}\right)$ but the treatment combination $\mathrm{M}_{3} \mathrm{P}_{2}$ is preparable treatment because it had less input and gets more output then control and other treatment combination. The result reveals by Parewa and Yadav (2014) that highest grain and straw yields can be obtained by the application of optimum doses of NPK in combination with FYM @ 10 tonnes $\mathrm{ha}^{-1}$ followed by $100 \%$ NPK. However, balanced application of NPK with FYM and bioinoculants were found high responses in the yield in the comparison of sub optimal and super optimal doses of NPK. Similarly, Plant height $(109.7 \mathrm{~cm})$ was highest in the treatment $\mathrm{M}_{4} \mathrm{P}_{3}$ and it was remained at par with $\mathrm{M}_{3} \mathrm{P}_{2}, \mathrm{M}_{3} \mathrm{P}_{3}$ and $\mathrm{M}_{4} \mathrm{P}_{2}$. Here, PGPR and zinc@ $2.5 \mathrm{~kg} \mathrm{ha}^{-1}$ enriched FYM + $40 \mathrm{~kg} \mathrm{ha}^{-1}$ $\mathrm{P}_{2} \mathrm{O}_{5}$ treatment combination was 
economically beneficial for the farmers due to low cost of inputs than other closest treatments. Increment in growth and yield may be due to the effect of PGPR and Zinc enriched FYM in which PGPR plays an important role in the nutrient acquisition $(\mathrm{P}$ solubilization and $\mathrm{N}$ fixation), stimulation of growth by producing growth hormones, so that rice plants reflected on enhancement in the growth and yield characteristics. Phytohormones like IAA and GA which promote the plant growth, cell division, breaking the special dormancies, hence encouraging the photosynthesis and assimilate accumulation in plant (El-Khawas and Adachi, 1999). Similar improvements in yield attributes have also been observed by Namvar and Khandan (2013). It is also concluded by Sharma at al., (2015) that the integrated use of $75 \%$ recommended dose of NPK fertilizer along with $5 \mathrm{t} \mathrm{FYM} \mathrm{ha}{ }^{-1}+\mathrm{BGA}+\mathrm{PSB}+5 \mathrm{~kg} \mathrm{Zn}$ $\mathrm{ha}^{-1}$ sustains rice production as well as improve the soil fertility status of Vertisols.

Table.1 Effect of PGPR and zinc enriched FYM and phosphorus levels on chlorophyll content (SPAD value) at $60 \mathrm{DAT}$ of rice

\begin{tabular}{|c|c|c|c|}
\hline \multirow{2}{*}{ Treatments } & \multicolumn{3}{|c|}{ Chlorophyll content (SPAD value) } \\
\hline & 2013-14 & 2014-15 & Pooled \\
\hline \multicolumn{4}{|c|}{ Enriched FYM } \\
\hline $\mathrm{M}_{0}$ & 32.05 & 32.40 & 32.23 \\
\hline $\mathrm{M}_{1}$ & 34.14 & 34.87 & 34.50 \\
\hline $\mathrm{M}_{2}$ & 35.40 & 36.15 & 35.78 \\
\hline $\mathrm{M}_{3}$ & 37.04 & 37.89 & 37.47 \\
\hline $\mathrm{M}_{4}$ & 37.51 & 38.47 & 37.99 \\
\hline $\mathrm{SEm} \pm$ & 0.56 & 0.61 & 0.31 \\
\hline $\mathrm{CD}(\mathrm{P}=0.05)$ & 1.60 & 1.73 & 0.88 \\
\hline \multicolumn{4}{|c|}{ Phosphorus Levels } \\
\hline $\mathrm{P}_{0}$ & 33.15 & 33.63 & 33.39 \\
\hline $\mathrm{P}_{1}$ & 34.71 & 35.46 & 35.09 \\
\hline $\mathrm{P}_{2}$ & 36.15 & 36.98 & 36.56 \\
\hline $\mathrm{P}_{3}$ & 36.90 & 37.75 & 37.32 \\
\hline SEm \pm & 0.50 & 0.54 & 0.27 \\
\hline $\mathrm{CD}(\mathrm{P}=0.05)$ & 1.43 & 1.55 & 0.78 \\
\hline
\end{tabular}


Table.2 Effect of PGPR and zinc enriched FYM and phosphorus levels on plant height, tillers hill ${ }^{-1}$, grains panicle ${ }^{-1}$ and test weight of rice

\begin{tabular}{|c|c|c|c|c|c|c|c|c|c|c|c|c|}
\hline \multirow{2}{*}{ Treatments } & \multicolumn{3}{|c|}{ Plant height $(\mathrm{cm})$} & \multicolumn{3}{|c|}{ Tillers hill ${ }^{-1}$} & \multicolumn{3}{|c|}{ Grains panicle $^{-1}$} & \multicolumn{3}{|c|}{ Test Weight (g) } \\
\hline & $\begin{array}{c}\text { 2013- } \\
14\end{array}$ & $\begin{array}{c}\text { 2014- } \\
15\end{array}$ & Pooled & $\begin{array}{c}2013- \\
14\end{array}$ & $\begin{array}{c}2014- \\
15\end{array}$ & Pooled & $\begin{array}{c}2013- \\
14\end{array}$ & $\begin{array}{c}\text { 2014- } \\
15\end{array}$ & Pooled & $\begin{array}{c}2013- \\
14\end{array}$ & $\begin{array}{c}\text { 2014- } \\
15\end{array}$ & Pooled \\
\hline \multicolumn{13}{|c|}{ Enriched FYM } \\
\hline $\mathrm{M}_{0}$ & 91.28 & 91.59 & 91.44 & 9.20 & 9.56 & 9.38 & 117.88 & 118.97 & 118.43 & 22.18 & 22.24 & 22.21 \\
\hline $\mathrm{M}_{1}$ & 95.78 & 96.85 & 96.31 & 10.63 & 11.39 & 11.01 & 122.73 & 124.48 & 123.60 & 22.58 & 22.78 & 22.68 \\
\hline $\mathrm{M}_{2}$ & 99.91 & 101.60 & 100.75 & 12.42 & 13.22 & 12.82 & 127.65 & 129.80 & 128.73 & 22.92 & 23.30 & 23.11 \\
\hline $\mathrm{M}_{3}$ & 104.41 & 106.02 & 105.21 & 13.73 & 14.76 & 14.24 & 131.09 & 133.42 & 132.26 & 23.36 & 23.93 & 23.65 \\
\hline $\mathrm{M}_{4}$ & 105.43 & 107.44 & 106.44 & 14.63 & 15.48 & 15.05 & 132.55 & 135.00 & 133.77 & 23.52 & 24.02 & 23.77 \\
\hline SEm \pm & 0.61 & 0.46 & 0.42 & 0.37 & 0.39 & 0.37 & 0.85 & 0.56 & 0.64 & 0.11 & 0.14 & 0.09 \\
\hline $\mathrm{CD}(\mathrm{P}=0.05)$ & 1.75 & 1.32 & 1.20 & 1.05 & 1.10 & 1.07 & 2.43 & 1.59 & 1.83 & 0.33 & 0.40 & 0.26 \\
\hline \multicolumn{13}{|c|}{ Phosphorus Levels } \\
\hline $\mathrm{P}_{0}$ & 94.08 & 94.53 & 94.30 & 9.99 & 10.40 & 10.19 & 120.54 & 121.42 & 120.98 & 22.40 & 22.54 & 22.47 \\
\hline $\mathrm{P}_{1}$ & 98.92 & 100.49 & 99.70 & 11.56 & 12.37 & 11.96 & 125.58 & 127.70 & 126.64 & 22.75 & 23.00 & 22.88 \\
\hline $\mathrm{P}_{2}$ & 101.39 & 103.15 & 102.27 & 12.99 & 13.87 & 13.43 & 128.61 & 130.96 & 129.79 & 23.06 & 23.54 & 23.30 \\
\hline $\mathrm{P}_{3}$ & 103.06 & 104.64 & 103.85 & 13.95 & 14.89 & 14.42 & 130.79 & 133.26 & 132.02 & 23.45 & 23.95 & 23.70 \\
\hline SEm \pm & 0.55 & 0.41 & 0.37 & 0.33 & 0.34 & 0.33 & 0.76 & 0.50 & 0.57 & 0.10 & 0.12 & 0.08 \\
\hline $\mathrm{CD}(\mathrm{P}=0.05)$ & 1.57 & 1.18 & 1.07 & 0.94 & 0.99 & 0.96 & 2.17 & 1.42 & 1.64 & 0.29 & 0.36 & 0.23 \\
\hline
\end{tabular}


Table.3 Effect of PGPR and zinc enriched FYM and phosphorus levels on grain yield, straw yield, biological yield and harvest index of rice

\begin{tabular}{|c|c|c|c|c|c|c|c|c|c|c|c|c|}
\hline \multirow{3}{*}{ Treatments } & \multicolumn{9}{|c|}{ Yield $\left(q\right.$ ha $\left.^{-1}\right)$} & \multirow{2}{*}{\multicolumn{3}{|c|}{$\begin{array}{c}\text { Harvest index } \\
(\%)\end{array}$}} \\
\hline & \multicolumn{3}{|c|}{ Grain } & \multicolumn{3}{|c|}{ Straw } & \multicolumn{3}{|c|}{ Biological } & & & \\
\hline & $\begin{array}{c}2013- \\
14\end{array}$ & $\begin{array}{c}2014- \\
15\end{array}$ & Pooled & $\begin{array}{c}2013- \\
14\end{array}$ & $\begin{array}{c}2014- \\
15\end{array}$ & Pooled & 2013-14 & $\begin{array}{c}2014- \\
15\end{array}$ & Pooled & $\begin{array}{c}2013- \\
14\end{array}$ & $\begin{array}{c}2014- \\
15\end{array}$ & Pooled \\
\hline \multicolumn{13}{|c|}{ Enriched FYM } \\
\hline $\mathrm{M}_{0}$ & 40.63 & 40.51 & 40.57 & 56.24 & 56.18 & 56.21 & 96.87 & 96.69 & 96.78 & 41.92 & 41.86 & 41.89 \\
\hline $\mathrm{M}_{1}$ & 46.93 & 48.64 & 47.78 & 64.64 & 67.36 & 66.00 & 111.57 & 115.99 & 113.78 & 42.04 & 41.91 & 41.97 \\
\hline $\mathrm{M}_{2}$ & 50.20 & 51.80 & 51.00 & 68.53 & 70.81 & 69.67 & 118.72 & 122.61 & 120.67 & 42.29 & 42.27 & 42.28 \\
\hline $\mathrm{M}_{3}$ & 55.26 & 56.17 & 55.71 & 74.76 & 76.32 & 75.54 & 130.01 & 132.48 & 131.25 & 42.49 & 42.39 & 42.44 \\
\hline $\mathrm{M}_{4}$ & 56.46 & 57.39 & 56.92 & 76.21 & 77.45 & 76.83 & 132.67 & 134.84 & 133.75 & 42.55 & 42.56 & 42.55 \\
\hline SEm \pm & 0.45 & 0.50 & 0.45 & 0.63 & 0.72 & 0.64 & 1.01 & 1.14 & 1.02 & 0.14 & 0.15 & 0.14 \\
\hline $\mathrm{CD}(\mathrm{P}=0.05)$ & 1.29 & 1.42 & 1.29 & 1.79 & 2.05 & 1.82 & 2.90 & 3.27 & 2.93 & 0.41 & 0.44 & 0.40 \\
\hline \multicolumn{13}{|c|}{ Phosphorus Levels } \\
\hline $\mathrm{P}_{0}$ & 44.62 & 44.58 & 44.60 & 61.39 & 61.44 & 61.42 & 106.01 & 106.02 & 106.02 & 42.06 & 41.98 & 42.02 \\
\hline $\mathrm{P}_{1}$ & 49.18 & 50.82 & 50.00 & 67.25 & 69.79 & 68.52 & 116.43 & 120.60 & 118.52 & 42.21 & 42.12 & 42.17 \\
\hline $\mathrm{P}_{2}$ & 52.04 & 53.46 & 52.75 & 71.01 & 72.68 & 71.85 & 123.05 & 126.14 & 124.60 & 42.27 & 42.36 & 42.31 \\
\hline $\mathrm{P}_{3}$ & 53.73 & 54.75 & 54.24 & 72.65 & 74.58 & 73.61 & 126.38 & 129.32 & 127.85 & 42.50 & 42.31 & 42.41 \\
\hline SEm \pm & 0.40 & 0.44 & 0.40 & 0.56 & 0.64 & 0.57 & 0.91 & 1.02 & 0.92 & 0.13 & 0.14 & 0.12 \\
\hline $\mathrm{CD}(\mathrm{P}=0.05)$ & 1.16 & 1.27 & 1.15 & 1.60 & 1.83 & 1.63 & 2.59 & 2.92 & 2.62 & NS & NS & NS \\
\hline
\end{tabular}


Table.4 Interactive effect of enriched FYM and phosphorus levels on plant height, grain yield, straw yield, and biological yield of rice (pooled data of 2 years)

\begin{tabular}{|c|c|c|c|c|c|c|c|c|c|c|c|c|c|c|c|c|}
\hline \multirow{2}{*}{ Treatments } & \multicolumn{4}{|c|}{ Plant height $(\mathrm{cm})$} & \multicolumn{4}{|c|}{ Grain yield $\left(q\right.$ ha $\left.^{-1}\right)$} & \multicolumn{4}{|c|}{ Straw yield $\left(q\right.$ ha $\left.^{-1}\right)$} & \multicolumn{4}{|c|}{ Biological yield $\left(q h^{-1}\right)$} \\
\hline & $\mathrm{P}_{0}$ & $\mathrm{P}_{1}$ & $\mathrm{P}_{2}$ & $\mathrm{P}_{3}$ & $\mathrm{P}_{0}$ & $\mathrm{P}_{1}$ & $\mathrm{P}_{2}$ & $\mathrm{P}_{3}$ & $\mathrm{P}_{0}$ & $\mathrm{P}_{1}$ & $\mathrm{P}_{2}$ & $\mathrm{P}_{3}$ & $\mathrm{P}_{0}$ & $\mathrm{P}_{1}$ & $\mathrm{P}_{2}$ & $\mathrm{P}_{3}$ \\
\hline $\mathrm{M}_{0}$ & 83.00 & 91.65 & 94.18 & 96.92 & 33.58 & 40.41 & 43.15 & 45.14 & 47.19 & 56.27 & 59.68 & 61.72 & 80.76 & 96.68 & 102.82 & 106.87 \\
\hline $\mathrm{M}_{1}$ & 88.65 & 96.53 & 99.77 & 100.30 & 39.54 & 47.58 & 51.25 & 52.77 & 55.79 & 65.53 & 70.40 & 72.27 & 95.33 & 113.11 & 121.66 & 125.04 \\
\hline $\mathrm{M}_{2}$ & 94.33 & 99.58 & 103.62 & 105.48 & 44.47 & 50.27 & 53.91 & 55.36 & 60.07 & 68.83 & 73.85 & 75.92 & 104.54 & 119.10 & 127.75 & 131.27 \\
\hline $\mathrm{M}_{3}$ & 101.75 & 104.92 & 106.70 & 107.48 & 51.85 & 55.24 & 57.44 & 58.31 & 70.67 & 75.91 & 77.35 & 78.22 & 122.52 & 131.14 & 134.79 & 136.53 \\
\hline $\mathrm{M}_{4}$ & 103.78 & 105.83 & 107.07 & 109.07 & 53.56 & 56.51 & 58.01 & 59.62 & 73.37 & 76.05 & 77.96 & 79.94 & 126.93 & 132.56 & 135.96 & 139.56 \\
\hline $\mathrm{SEm} \pm$ & \multicolumn{4}{|c|}{0.84} & \multicolumn{4}{|c|}{0.90} & \multicolumn{4}{|c|}{1.27} & \multicolumn{4}{|c|}{2.05} \\
\hline $\begin{array}{c}\mathrm{CD} \\
(\mathrm{P}=0.05)\end{array}$ & \multicolumn{4}{|c|}{2.39} & \multicolumn{4}{|c|}{2.58} & \multicolumn{4}{|c|}{3.64} & \multicolumn{4}{|c|}{5.86} \\
\hline
\end{tabular}

$\mathbf{M}_{0}=$ Control, $\mathbf{M}_{1}=$ only FYM @ $5 \mathrm{t} \mathrm{ha}^{-1}, \mathbf{M}_{2}=$ PGPR enriched FYM @ $5 \mathrm{t} \mathrm{ha}^{-1}, \mathbf{M}_{3}=$ PGPR and Zn at $2.5 \mathrm{~kg} \mathrm{ha}^{-1}$ enriched FYM @ $5 \mathrm{t} \mathrm{ha}{ }^{-1}$ and $\mathbf{M}_{4}=$ PGPR and $\mathrm{Zn}$ at $5 \mathrm{~kg} \mathrm{ha}^{-1}$ enriched FYM@ $5 \mathrm{t} \mathrm{ha}^{-1} . \mathbf{P}_{\mathbf{0}}=$ Control, $\mathbf{P}_{1}=20, \mathbf{P}_{2}=40$ and $\mathbf{P}_{3}=60 \mathrm{~kg} \mathrm{P}_{2} \mathrm{O}_{5}$. 
Lavakush et al., (2014) have also reported that $60 \mathrm{~kg} \mathrm{ha}^{-1}$ phosphorus gave highest enhancement in growth parameters while approximate similar enhancement in growth attribute can be obtained by combined application of PGPR and $30 \mathrm{~kg} \mathrm{ha}{ }^{-1}$ phosphorus. So that treatment combination of PGPR with $30 \mathrm{~kg} \mathrm{ha}^{-1}$ phosphorus was found economically cheaper than with $60 \mathrm{~kg} \mathrm{ha}^{-1}$ and beneficial at farmer's level. Afzal et al., (2005) observed that Grain yield and biological yield were significantly increased by application of the PSM, phosphorus and FYM. Highest yield was recorded when PSM was used with phosphorus alone or along with organic matter. It is concluded that PSM alone or along with other combinations produced profound effect on grain yield, biological yield, tillers per $\mathrm{m}^{-2}$ and seed phosphorus content.

Here, it was found that all the growth and yield parameters were significantly influenced by PGPR and Zn enriched FYM and phosphorus levels. It may be concluded that application of enriched FYM (PGPR and Zinc @ $2.5 \mathrm{~kg} \mathrm{ha}^{-1}$ ) at $40 \mathrm{~kg} \mathrm{P}_{2} \mathrm{O}_{5} \mathrm{ha}^{-1}$ is best option for higher productivity and profitability for growing of rice without endangering the soil health. Combination of enriched FYM and phosphorus applied to rice crop will be carry-over beneficial effects on succeeding crop on the farmer's levels. So, we can minimize excess use of fertilizers and also increase the fertilizer use efficiency by enrichment of FYM with PGPR and Zinc. Therefore, it was conferred that $20 \mathrm{~kg}_{2} \mathrm{O}_{5}$ and $2.5 \mathrm{~kg} \mathrm{Zn}$ could be saved and optimum grain and straw yield of rice could be obtained with application of $5 \mathrm{t} \mathrm{ha}^{-1}$ FYM enriched with PGPR consortium + Zn @ 2.5 $\mathrm{kg} \mathrm{ha}^{-1}, 120 \mathrm{~kg} \mathrm{~N}, 40 \mathrm{~kg} \mathrm{P}_{2} \mathrm{O}_{5} \mathrm{ha}^{-1}$ and $60 \mathrm{~kg}$ $\mathrm{K}_{2} \mathrm{O} \mathrm{ha}^{-1}$ in the soils of eastern Uttar Pradesh.

\section{Acknowledgements}

Authors are gratefully acknowledge for the financial support to the UGC, Govt. of India for financial assistance for completing this research work.

\section{References}

Afzal, A., Ashraf, M., Saeed, A., Asad and Farooq, M. 2005. Effect of Phosphate Solubilizing Microorganisms on Phosphorus Uptake, Yield and Yield Traits of Wheat (Triticum aestivum L.) in Rainfed Area. Int. J. Agri. Biol., 7(2): 207-209.

Brady, N.C. and Weil, R.R. 2007. Nature and Properties of Soils, Thirteenth Edition, Dorling Kindersley (India) Pvt. Ltd., New Delhi.

El-Khawas, H. and Adachi, K. 1999. Identification and quantification of auxins in culture media of Azospirillum and Klebsiella and their effect on rice roots. Biol. Fertility of Soils, 28: 377381.

FAO. 2014. Food and Agriculture Organization of the United Nations Statistics Division http:/faostat.fao.org/ download/Q/QC/E.

Fitzgerald, M.A., McCouch, S.R. and Hall, R.D. 2009. Not just a grain of rice: the quest for quality. Trends in Plant Sci., 14: 133-139.

Havlin, J.H., Tisdale, S.L., Beaton, J.D. and Nelson, W.L. 2007. Soil Fertility and Fertilizers: An Introduction to Nutrient Management, Seventh Edition, Dorling Kindersley (India) Pvt. Ltd. pp. 1-261.

Jena, P.K., Rao, C.P. and Subbaiah, G. 2006. Effect of zinc management practices on growth, yield and economics in rice. Crop Production, 43(4): 326-328.

Joseph, B., Patra, R.R. and Lawrence, R. 2007. Characterization of plant growth promoting Rhizobacteria associated with chickpea (Cicer arietinum L). Int, J. Plant Production, 1: 141-152.

Kloepper, J.W., Reddy, S.M., RodreguezKabana, R., Kenney, D.S., Kokalis- 
Burelle, N. and Ochoa, N.M. 2004. Application for Rhizobacteria in Transplant Production and Yield Enhancement. Acta Horticulturae, 631: 217-229.

Kumar, D., Chauhan, R.P.S., Singh, B.B., and singh, V.P. 1999. Response of rice to zinc sulphate incubated and blended with organic materials in sodic soil. Indian J. Agri. Sci., 69(6): 402-405.

Kumar, V. and Singh, A.P. 2010. Long-term effect of green manuring and farmyard manure on yield and soil fertility status in rice-wheat cropping system. J. Indian Soc. Soil Sci., 58(4): 409-412.

Lavakush, Yadav, J., Verma, J.P., Jaiswal, D.K. and Kumar, A. 2014. Evaluation of PGPR and different concentration of phosphorus level on plant growth, yield and nutrient content of rice (Oryza sativa). Ecol. Engi., 62: 123-128.

Laxminarayana, K. 2006. Effect of integrated use of inorganic and organic manures on soil properties, yield and nutrient uptake of rice in Ultisols of Mizoram. $J$. Indian Society of Soil Sci., 54: 120-123.

Laxminarayana, K. and Patiram. 2006. Effect of integrated use of inorganic, biological and organic manures on rice productivity and soil fertility in Ultisols of Mizoram. J. Indian Society of Soil Sci., 54: 213-220.

Liu, G., Bernhardt, L., Jia, H., Wamishe, A. and Jia, Y. 2008. Molecular characterization of the recombinant inbred line population derived from a Japonica Indica rice cross. Euphytica, 159: 73-82.

Meena, M.E., Patel, K.P. and Rathod, D.D. 2006. Effect of $\mathrm{Zn}$ and $\mathrm{Fe}$ enriched FYM on mustard yield and micronutrient Availability in loamy sand soil (typic haplustept) of Anand. $J$. Indian Society of Soil Sci., 54(4): 495499.

Meena, R.K., Nanda, G., Neupane, M.P. and
Singh, S.P. 2015. Effect of phosphorus levels and bio-organic sources on growth attributes and yield of rice. The Ecoscan, 9(1\&2): 579-582.

Namvar, A. and Khandan, T. 2013. Response of wheat to mineral nitrogen fertilizer and biofertilizer (Azotobacter sp. and Azospirillum sp.) inoculation under different levels of weed interference. Ekologia, 59(2): 85-94.

Parewa, H.P. and Yadav, J. 2014. Response of fertility levels, FYM and bioinoculants on yield attributes, yield and quality of wheat. Agri. Sustainable Develop., 2(1): 5-10.

Pathak, P., Kapil, U., Dwivedi, S.N. and Singh, R. 2008. Serum zinc levels amongst pregnant women in a rural block of Haryana state, India. Asia Pacific J. Clin. Nutrition, 17: 276-279.

Patil, R.B. and Varade, P.A. 1998. Microbial population in rhizosphere as influenced by high input rates of fertilizer application to sorghum on a Vertisol. $J$. Indian Soc. Soil Sci., 46(2): 223-227.

Ponmurugan, P.C. and Gopi, C. 2006. In vitro production of growth regulators and phosphates activity by phosphate solubilising bacteria. African $J$. Biotechnol., 5: 348-350.

Sharma, A., Rawat, U.S. and Yadav, B.K. 2012. Influence of phosphorus levels and phosphorus solubilizing fungi on yield and nutrient uptake by wheat under subhumid region of Rajasthan, India. Int. Scholarly Res. Network Agron., 1-9.

Sharma, G.D., Thakur R., Chouhan, N., and Keram, K.S. 2015. Effect of Integrated Nutrient Management on Yield, Nutrient Uptake, Protein Content, Soil Fertility and Economic Performance of Rice (Oryza sativa L.) in a Vertisol. J. Indian Society of Soil sci., 63(3): 320326.

Singh, A.P. 2010. Deteriorating soil health 
and its management for higher crop production. J. Indian Soc. Soil Sci., 58: 41-52.

Singh, C.P. 1987. Preparation of high grade compost by an enrichment technique. I. Effect of enrichment on organic matter decomposition. Biol. Agri. Horticulture, 5: 41-49.

Sudhakar, P.C., Singh, J.P., Singh, Y. and Singh, R. 2006. Effect of graded fertility levels and silicon sources on crop yield, uptake and nutrient-use efficiency in rice (Oryza sativa). Indian J. Agron., 51(3): 186-88.

Veeraputhiran, R. and Balasubramanian. R. 2013. Evaluation of bispyribac-sodium in transplanted rice. Indian J. Weed Sci., 45(1): $12-15$.

Vessey, J.K., Pawlowski, K. and Bergman, B. 2004. Root-based $\mathrm{N}_{2}$ - fixing symbioses: Legumes, actinorhizal plants, Parasponia sp., and cycads. Plant and Soil, 266: 205-230.

\section{How to cite this article:}

Kanhaiya Lal Regar and JanardanYadav. 2017. Influence of PGPR and Zinc Enriched FYM on Growth and Yield of Rice at Different Levels of Phosphors in an Inceptisol of Varanasi. Int.J.Curr.Microbiol.App.Sci. 6(4): 1453-1464. doi: https://doi.org/10.20546/ijcmas.2017.604.177 